\title{
Global patterns of macroinvertebrate biomass in marine intertidal communities
}

\author{
Anthony Ricciardi, Edwin Bourget* \\ GIROQ, Département de biologie, Université Laval, Québec (Québec) G1K 7P4, Canada
}

\begin{abstract}
We examine global patterns of benthic macroinvertebrate biomass and its distribution among functional teeding guilds in marine intertidal communities. Variation in ash-free dry biomass was related to physical variables (mean annual air and water temperatures, sediment grain size, intertidal slope, tide range and type, wave height and exposure) by least-squares regression analysis of data for 36 rocky shores and 245 sedimentary shores. Linear combinations of physical variables explain up to $44 \%$ of the variance in total biomass on sedimentary shores and $40 \%$ of the variance in the biomass on rocky shores. Grain size and wave exposure are the best single predictors of total biomass for sedimentary shores and rocky shores, respectively. Biomass estimates peak in temperate regions and are an order of magnitude higher on rocky shores than on sedimentary shores. In fact, macroinvertebrate biomass on temperate rocky shores attains levels 10 to 100 times higher than those documented for other benthic marine environments. Suspension feeders tend to dominate temperate intertidal communities (they typically comprise $>30$ to $60 \%$ of the macroinvertebrate biomass), reflecting the importance of benthic-pelagic coupling in these ecosystems. Contrary to consumer stress models for rocky shores, there is no compelling evidence for biomass limitation of grazers and carnivores at high wave exposure.
\end{abstract}

KEY WORDS: Macrofauna $\cdot$ Biomass $\cdot$ Benthos - Intertidal $\cdot$ Rocky shore $\cdot$ Sandy beach

\section{INTRODUCTION}

Macroscopic analyses of emergent patterns of organismal abundance, distribution, and diversity over large geographic scales have great potential for testing the generality of underlying mechanisms that structure the natural world (e.g. Currie \& Fritz 1993, Brown 1995, Pearson \& Carroll 1998, Lawton 1999). To date, such analyses have been used to address questions predominantly in terrestrial ecology. While marine intertidal shores are model systems for ecological research on population and community dynamics, large-scale quantitative analyses of these systems have rarely been attempted (but see Dexter 1992, McLachlan et al. 1993). This is indicated by the paucity of interecosystem comparisons in the marine literature; for example, less than $8 \%(47 / 630)$ of all field studies published in 'Limnology \& Oceanography' and 'Marine Ecology Progress Series' in 1996 made statistical comparisons of 2 or more

\footnotetext{
- Addressee for correspondence.

E-mail: edwin.bourget@fsg.ulaval.ca
}

ecosystems (A. Ricciardi pers. obs.). Consequently, the generality of numerous accepted paradigms derived from experimental studies of intertidal communities is untested (Underwood \& Denley 1984, Foster 1990).

Because intertidal benthic invertebrates are a major link in the energy flow between primary producers and larger consumers such as fish and shorebirds (McDermott 1983, Baird et al. 1985, Reise 1985, DeLancey 1989, Edgar \& Shaw 1995), and are of substantial commercial value (FAO 1997), a predictive understanding of spatial variation in macroinvertebrate biomass has both fundamental and applied importance. Attempts to characterize this variation are challenged by the complex suite of physical and biological factors that structure coastal communities (reviewed by Connell 1975, McLachlan 1983, Dayton 1984, Underwood \& Denley 1984, Foster et al. 1988. Menge \& Farrell 1989, Brown \& McLachlan 1990). However, in recent decades, several studies have quantitatively related regional variation in intertidal biomass to physical variables such as sediment grain size, shore slope, water temperature, and exposure to 
waves (e.g. Eleftheriou \& Nicholson 1975, McQuaid \& Branch 1984, 1985, McLachlan 1990, 1996, Jaramillo \& McLachlan 1993, Jaramillo et al. 1993, McLachlan et al. 1993, Bustamante \& Branch 1996a). Synoptic surveys of South African rocky shores have shown that macrofaunal biomass increases with increasing wave exposure (McQuaid \& Branch 1984, 1985, Bustamante \& Branch 1996a). In a study of 23 wave-exposed sandy beaches, McLachlan (1990) found wave height and beach slope to be significant correlates of macrofaunal biomass. A similar analysis of a larger dataset concluded that both the height and periodicity of waves play significant but weak roles in controlling biomass on exposed sandy beaches (McLachlan et al. 1993). The generality of these relationships remains to be tested across a broad range of latitudes and habitat types.

In this paper, we extend the efforts of previous studies by statistically linking intertidal macroinvertebrate biomass to physical variables over a broad range of latitudes, geographic regions, and habitat types, in order to identify important environmental predictors of biomass and to explain patterns of its distribution among major functional feeding guilds. Specifically, we examine the effects of hydrodynamic variables (e.g. grain size, wave exposure, tide range) and climatic variables (mean annual air and water temperature) on the macroinvertebrate biomass of sedimentary and rocky shores worldwide.

\section{METHODS}

Estimates of intertidal macroinvertebrate biomass were extracted from marine literature published after 1960, using Aquatic Sciences and Fisheries Abstracts on CD-ROM and references cited by review articles. We added new field data for intertidal sites in the St. Lawrence River estuary (E. Bourget unpubl. data) and Icelandic fjords (A. Ingólfsson, Institute of Biology, University of Iceland, pers. comm.). Data were thus obtained for 36 rocky shores and 245 sedimentary shores (sandy beaches and mudflats) (Table 1). We included estuarine sites with mean annual salinities $>20 \mathrm{~g} \mathrm{l}^{-1}$, as preliminary analysis showed no correlation between biomass and salinity above this threshold.

In the various source studies, samples were collected using corers (on sedimentary shores) or by hand from quadrats (on rocky shores) and sieved through screens with apertures ranging from 0.25 to 1.6 (median 1.0) $\mathrm{mm}$. Biomass estimates used in our analysis represent values averaged across the width of the intertidal zone. Data reported as biomass per linear meter of beach ( $g$ $\mathrm{m}^{-1}$ ) were used when information on intertidal width allowed these values to be expressed as $\mathrm{g} \mathrm{m}^{-2}$. Because ash-free dry weight (AFDW) is the most ecologically meaningful measure of biomass (Crisp 1984), we converted all biomass estimates to AFDW using general conversion factors (Ricciardi \& Bourget 1998). Onethird of the biomass estimates for sedimentary shores, and half of those for rocky shores, are annual means. In addition, we included estimates averaged over days or months within a summer season. Differences associated with the use of annual and summer estimates were tested using a categorical dummy variable $0=$ summer, 1 = annual) in all regression models. Whenever possible, biomass estimates were also obtained for individual functional feeding guilds (suspension feeders, deposit feeders, carnivores/scavengers, and herbivorous grazers). Each species was assigned to a guild based on its dominant dietary habit as determined from the literature (e.g. Fauchald \& Jumars 1979, Barnes 1986, Brown \& McLachlan 1990, Squires 1990).

Hydrodynamic and climatic predictor variables were chosen on the basis of published studies suggesting their potential influence on intertidal macroinvertebrate biomass. For sedimentary shores, hydrodynamic variables included mean grain size, mean wave height, maximum tide range, and intertidal slope. In addition, categorical exposure variables (EXP1, EXP2) were used to group sheltered sites receiving very limited wave action $(E X P 1=0, E X P 2=0)$, sites fully exposed to waves $(\operatorname{EXP} 1=0, \mathrm{EXP} 2=1)$, and sites of intermediate exposure $(\operatorname{EXP} 1=1, \mathrm{EXP} 2=0)$. These categories were assigned solely on the basis of physical information from the source studies (or atlases) on the degree to which a site was exposed to wave action or prevailing winds; any site that was only partially exposed to prevailing winds was classified as 'intermediate'. Another categorical variable was added to distinguish diurnal and semidiurnal (including mixed) tide types. Air and water temperature variables, the latter already shown to be correlated with benthic production (Tumbiolo \& Downing 1994), were also included as potential predictors. Site-specific estimates of mean annual air and water temperatures, as well as maximum tide range and type, were obtained from the source studies or from Gorshkov (1978). Latitudinal trends in intertidal biomass were also examined.

Although rocky shores may be covered by sand and gravel, we did not apply a grain size variable to them. Also, insufficient data were available to determine the relationships of wave height, intertidal slope, and tide type to rocky shore biomass. Thus, a total of 5 predictors (latitude, exposure, tide range, air and water temperature) were tested for rocky shores, while 9 were tested for sedimentary shores. Finally, because sieve mesh size varies among studies and may potentially bias biomass estimates when small organisms domi- 
nate intertidal assemblages, we tested this methodological variable in all regression models for sedimentary shores. The complete dataset is available from the Depository of Unpublished Data, CISTI, National Research Council, Ottawa, Canada.

Regression procedures. Relationships between biomass and the predictor variables were modeled by least-squares linear regression (Rawlings 1988) using SAS procedures (SAS Institute Inc. 1988); the error term associated with each predictor variable was assumed to be small compared with that of the biomass variable. Biomass values spanned several orders of magnitude, and were log-transformed because the mean $(m)$-variance $\left(s^{2}\right)$ relationship of the data $\left(s^{2}=\right.$
$1.74 \mathrm{~m}^{2.01} ; \mathrm{r}^{2}=0.86$ ) suggested that this was the most appropriate transformation to reduce the influence of large values and stabilize variance (Downing 1979). Mean grain size estimates for sedimentary shores were standardized to their respective phi $(\phi)$ values (i.e. the negative log base 2 of the grain size in $\mathrm{mm}$ ). Residual plots were inspected to determine whether transformation of other predictor variables was appropriate. Multiple regressions were generated by a stepwise selection technique with significant levels of 0.15 and 0.10 chosen a priori for variable entry and retention, respectively. These regression models included categorical variables (following Hardy 1993) and were generated separately for rocky and sedimentary shore

Table 1. Sources of data used in regression analyses of intertidal macroinvertebrate biomass

\begin{tabular}{|c|c|c|c|}
\hline Region & $\begin{array}{l}\text { No. } \\
\text { sites }\end{array}$ & $\begin{array}{l}\text { Latitude } \\
\text { range }\end{array}$ & Source \\
\hline \multicolumn{4}{|l|}{ Arctic/subarctic } \\
\hline Rocky shores & 3 & $65^{\circ} \mathrm{N}-69^{\circ} \mathrm{N}$ & Ingólfsson (1996, unpubl. data), Zenkevitch (1963) \\
\hline Sedimentary shores & 4 & $64^{\circ} \mathrm{N}-73^{\circ} \mathrm{N}$ & Ellis (1960), Ingólfsson (1996, unpubl. data), Olaffson (1991) \\
\hline \multicolumn{4}{|l|}{ Western Atlantic } \\
\hline Rocky shores & 3 & $48^{\circ} \mathrm{N}$ & Archambault \& Bourget (1996), Bourget (unpubl data) \\
\hline Sedimentary shores & 36 & $35^{\circ} \mathrm{S}-49^{\circ} \mathrm{N}$ & $\begin{array}{l}\text { Sanders et al. (1962), Moore et al. (1968), Hughes \& Thomas (1971), Dexter } \\
(1972,1979), \text { Edwards (1973), Croker et al. (1975), Maurer (1977), Holm (1978), } \\
\text { Larsen (1979), Maurer \& Aprill (1979), Garlo (1980), Swennen et al. (1982), } \\
\text { Bourget \& Messier (1983), McDermott (1983), Schwinghamer et al. (1986), } \\
\text { Defeo et al. (1992), Hubertz et al. (1994), Heck et al. (1995) }\end{array}$ \\
\hline \multicolumn{4}{|l|}{ Eastern Atlantic } \\
\hline Rocky shores & 11 & $34^{\circ} \mathrm{S}$ & McQuaid \& Branch $(1984,1985)$ \\
\hline Sedimentary shores & 87 & $34^{\circ} \mathrm{S}-59^{\circ} \mathrm{N}$ & $\begin{array}{l}\text { Ushakov (1965), Seed \& Lowry (1973), Eleftheriou \& Nicholson (1975), } \\
\text { Eleftheriou \& Mclntyre (1976), Hibbert (1976), Withers (1977), Koop \& Griffiths } \\
\text { (1982), Bally (1983, 1987), McLachlan (1985a, 1996), Tarr et al. (1985), Warwick } \\
\text { \& Ruswahyuni (1987), Donn \& Cockcroft (1989), Dewarumez et al. (1991), } \\
\text { Kalejta \& Hockey (1991), Wolff et al. (1993), Arias \& Drake (1994), McLusky et } \\
\text { al. (1994), Sprung (1994), Bachelet et al. (1996) }\end{array}$ \\
\hline \multicolumn{4}{|l|}{ Mediterranean } \\
\hline Sedimentary shore & 1 & $43^{\circ} \mathrm{N}$ & Massé (1972) \\
\hline \multicolumn{4}{|l|}{ Gulf of Mexico } \\
\hline Sedimentary shores & 5 & $27^{\circ} \mathrm{N}-30^{\circ} \mathrm{N}$ & Bloom et al. (1972), Shelton \& Robertson (1981) \\
\hline \multicolumn{4}{|l|}{ North Sea } \\
\hline Sedimentary shores & 36 & $51^{\circ} \mathrm{N}-59^{\circ} \mathrm{N}$ & $\begin{array}{l}\text { Gray \& Rieger (1971), Beukema (1974), Kay \& Knights (1975), Wolff \& Wolff } \\
\text { (1977), Reise (1985), Möller (1986), McLusky (1987), Eleftheriou \& Robertson } \\
\text { (1988), Meire et al. (1991), Kristensen (1993), Reise et al. (1994) }\end{array}$ \\
\hline \multicolumn{4}{|l|}{ Pacific } \\
\hline Rocky shores & 15 & $33^{\circ} \mathrm{N}-48^{\circ} \mathrm{N}$ & $\begin{array}{l}\text { Glynn (1965), Batzli (1969), Littler (1980), Straughan (1982), Fuji \& Nomura } \\
\text { (1990), Littler et al. (1991), Iwasaki (1995) }\end{array}$ \\
\hline Sedimentary shores & 25 & $44^{\circ} \mathrm{S}-48^{\circ} \mathrm{N}$ & $\begin{array}{l}\text { Pamatmat (1968), Dexter (1972, 1979), Nichols (1977), McLachlan (1990), } \\
\text { Jaramillo et al. (1993), McLachlan et al. (1993), Edgar \& Shaw (1995), Haynes \& } \\
\text { Quinn (1995) }\end{array}$ \\
\hline \multicolumn{4}{|l|}{ Indian Ocean } \\
\hline Rocky shores & 4 & $30^{\circ} \mathrm{S}-49^{\circ} \mathrm{S}$ & McLachlan et al. (1981a), Lawrence \& McClintock (1987), Fielding et al. (1994) \\
\hline Sedimentary shores & 51 & $49^{\circ} \mathrm{S}-16^{\circ} \mathrm{N}$ & $\begin{array}{l}\text { McIntyre (1968), Trevallion et al. (1970), Eleftheriou \& Jones (1976), Hughes \& } \\
\text { Gamble (1977), McLachlan (1977a,b, 1985b, 1990), Ansell et al. (1978), Dye et } \\
\text { al. (1981), McLachlan et al. (1981b), Woolridge et al. (1981), Broom (1982), } \\
\text { Wendt \& McLachlan (1985), Kurian \& Baba (1987), Warwick \& Ruswahyuni } \\
\text { (1987), Erftemeijer \& Swenner (1990), Edgar \& Shaw (1995) }\end{array}$ \\
\hline
\end{tabular}


data. As the latter data set included a few sites where macrofauna were absent, biomass values were transformed as $\log _{10}(x+0.01)$.

Statistical treatment of zero values. The constant scaling parameter $b$ in the $\log _{10}(x+b)$ transformation is generally chosen to represent the lowest detectable non-zero value. However, because the detection limit varies among the source studies used in our analysis, we cannot select a representative scaling parameter that will correct for the numerous zero values obtained for functional feeding guilds in our sedimentary shore data. The number of zeroes obtained were 19 (out of 83 estimates) for suspension feeders, 8 (of 83 estimates) for carnivores, 14 (of 83 estimates) for deposit feeders, and 50 (of 81 estimates) for grazers. Preliminary regression analysis showed that the choice of scaling parameter in logarithmic transformation influenced the coefficient of determination $\left(R^{2}\right)$ for models involving functional feeding guilds. Preliminary analyses using the fourth-root transformation (Downing 1979) showed similar strong biases from zero values and failed to achieve the criterion for normality. In fact, there is no known transformation that will correct for the presence of zeroes (McArdle et al. 1990); thus zero values obtained for each functional feeding guild in sedimentary shore data were omitted a priori from regression analysis. Even after exclusion of zeroes, biomass estimates for each functional feeding guild

Table 2. Ranges and median values for variables used in regression analyses

\begin{tabular}{|c|c|c|c|}
\hline & Range (min-max) & Median & $\mathrm{N}$ \\
\hline \multicolumn{4}{|l|}{ Rocky shores } \\
\hline Total biomass $\left(\mathrm{g} \mathrm{m}^{-2}\right)$ & $7.34-1143.9$ & 79.1 & 36 \\
\hline Suspension feeders $\left(\mathrm{g} \mathrm{m}^{-2}\right)$ & $0.3-1089$ & 35.72 & 24 \\
\hline Carnivores $\left(\mathrm{g} \mathrm{m}^{-2}\right)$ & $0.02-33.6$ & 3.6 & 21 \\
\hline Deposit feeders $\left(\mathrm{g} \mathrm{m}^{-2}\right)^{d}$ & $0.003-4.7$ & 0.9 & 19 \\
\hline Grazers $\left(\mathrm{g} \mathrm{m}^{-2}\right)$ & $0.31-97.8$ & 22.9 & 23 \\
\hline Air temperature $\left({ }^{\circ} \mathrm{C}\right)$ & $0.3-21.2$ & 15.8 & 36 \\
\hline Water temperature $\left({ }^{\circ} \mathrm{C}\right)$ & $4-22.7$ & 16.0 & 36 \\
\hline Tide range $(\mathrm{m})$ & $0.98-4.8$ & 1.75 & 36 \\
\hline \multicolumn{4}{|l|}{ Sedimentary shores } \\
\hline Total biomass $\left(\mathrm{g} \mathrm{m}^{-2}\right)$ & $0-380.4$ & 3.7 & 245 \\
\hline Suspension feeders $\left(\mathrm{g} \mathrm{m}^{-2}\right)^{\mathrm{d}}$ & d $0.004-339.8$ & 1.37 & 64 \\
\hline Carnivores $\left(\mathrm{g} \mathrm{m}^{-2}\right)^{a}$ & $0.02-16.29$ & 0.14 & 75 \\
\hline Deposit feeders $\left(\mathrm{g} \mathrm{m}^{-2}\right)^{a}$ & $0.001-29.51$ & 1.21 & 69 \\
\hline Grazers $\left(\mathrm{g} \mathrm{m}^{-2}\right)^{\mathrm{a}}$ & $0.001-9.7$ & 0.18 & 31 \\
\hline Air temperature $\left({ }^{\circ} \mathrm{C}\right)$ & $-14.9-27.8$ & 11.9 & 245 \\
\hline Water temperature $\left({ }^{\circ} \mathrm{C}\right)$ & $1.0-29.0$ & 12.1 & 245 \\
\hline Tide range $(\mathrm{m})$ & $0.1-15.0$ & 2.7 & 239 \\
\hline Wave height (m) & $0.3-3.2$ & 1.3 & 53 \\
\hline Slope $(\%)$ & $0.1-20.0$ & 3.6 & 105 \\
\hline Sediment grain size $(\phi)$ & $-1.23-7.5$ & 2.25 & 212 \\
\hline
\end{tabular}

spanned 3 to 5 orders of magnitude and included numerous small values, i.e. $<1 \mathrm{~g} \mathrm{~m}^{-2}$ (Table 2 )

We used discriminant function analysis to examine the presence or absence (zero biomass) of individual feeding guilds on sedimentary shores in relation to physical environmental factors. We first used a stepwise discriminant analysis to select predictor variables that best distinguished sites with and without the particular feeding guild, and then ran all significant predictors in a second analysis to produce linear discriminant functions (SAS Institute Inc. 1988). The ability of the discriminant functions to correctly classify the presence or absence of a particular feeding guild was assessed by an F-test on the Wilks' lambda statistic. The number of correctly classified sites for both categories are presented.

\section{RESULTS}

Macroinvertebrate biomass estimates for sedimentary shores do not vary linearly with latitude, but peak values $\left(<380 \mathrm{~g} \mathrm{~m}^{-2}\right)$ occur in north and south temperate

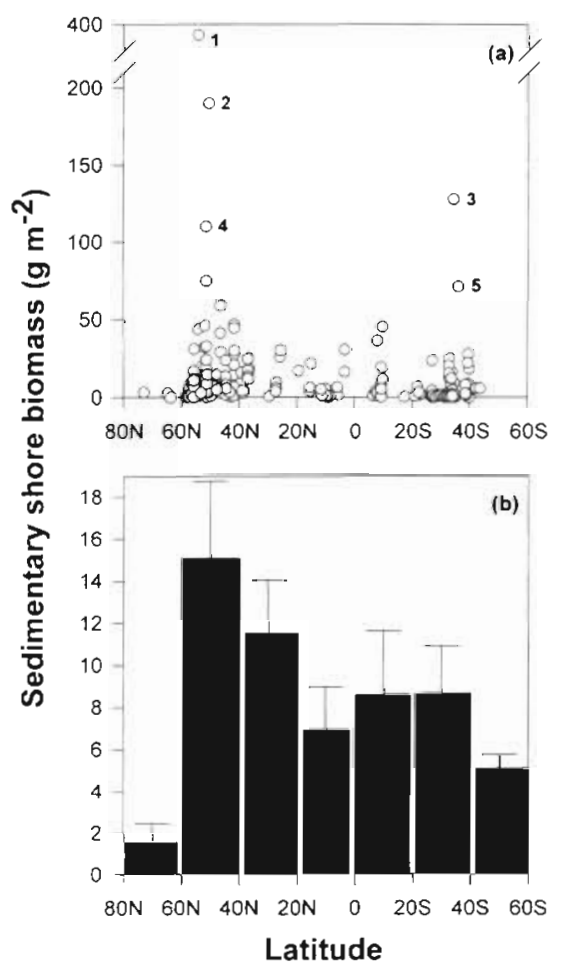

Fig. 1. Latitudinal distribution of biomass (ash-free dry weight) estimates for macroinvertebrates on sedimentary shores. (a) Scatterplot of data: 1, Konigshafen (Germany); 2, Hamble Spit (England); 3, Maitland River (South Africa); 4, Oosterschelde (Netherlands); 5, Barker Inlet (Australia). (b) Mean biomass ( \pm SE) for $20^{\circ}$ latitudinal intervals. Interval size was chosen to include a minimum of at least 3 data points per interval 
regions (Fig. 1). The highest estimates of any intertidal system (500 to $1150 \mathrm{~g} \mathrm{~m}^{-2}$ ) are found on temperate rocky shores. Macroinvertebrate biomass in temperate regions is 14 times higher on rocky shores than on sedimentary shores, owing to dense populations of suspension feeders and grazers (Fig. 2) that account for an average $55 \%$ and $35 \%$ of the total biomass, respectively. On temperate sedimentary shores, by contrast, suspension feeders typically comprise about 35\%, deposit feeders $\sim 30 \%$, carnivores $\sim 30 \%$, and grazers $5 \%$ of the macroinvertebrate biomass.

\section{Effects of individual physical variables on intertidal biomass}

\section{Rocky shores}

There are some marked differences in the effects of physical factors on rocky and sedimentary shore fauna. On rocky shores, total macroinvertebrate biomass is correlated weakly with mean annual water temperature (Fig. 3) and strongly with wave exposure (Fig. 4). Mean annual water temperature has positive effects on carnivores $\left(\mathrm{r}^{2}{ }_{\text {adj }}=0.14, \mathrm{p}=0.050\right)$ and grazers $\left(\mathrm{r}^{2}{ }_{\mathrm{ad} \mathrm{d}}=\right.$ $0.12, p=0.059$ ). Wave exposure has a strong influence only on suspension-feeder biomass (Fig. 5). Total biomass is also correlated negatively with tide range $\left(\mathrm{r}^{2}{ }_{\mathrm{adj}}\right.$ $=0.08, p=0.049$ ); large tide ranges are associated with reduced biomass estimates for carnivores $\left(r^{2}\right.$ adj $=0.16$, $\mathrm{p}=0.039)$ and grazers $\left(\mathrm{r}^{2}{ }_{\mathrm{ad}}=0.11, \mathrm{p}=0.066\right)$, but have no apparent effect on suspension feeders and deposit feeders.

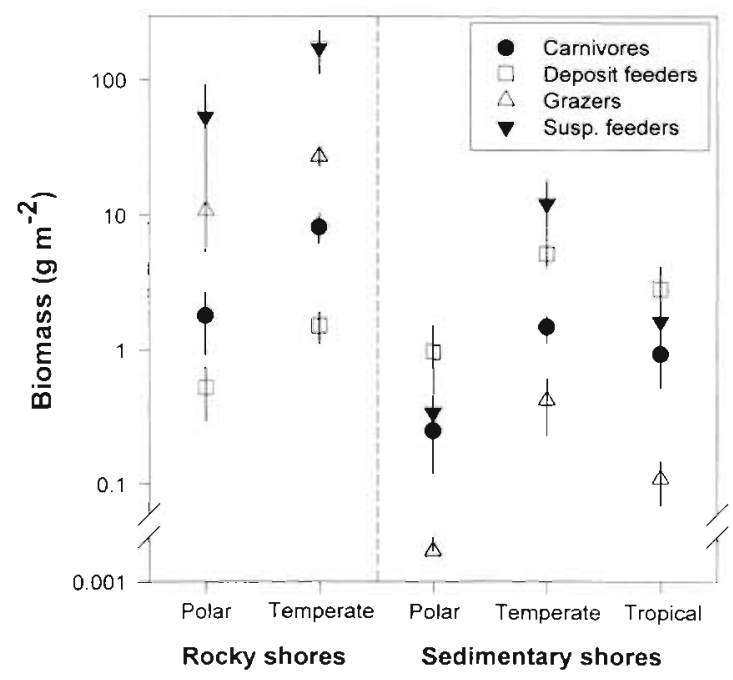

Fig. 2. Distribution of biomass among functional feeding guilds on polar $\left(>60^{\circ} \mathrm{N}\right)$, temperate $\left(25^{\circ}\right.$ to $\left.60^{\circ} \mathrm{N}, \mathrm{S}\right)$, and tropical $\left(0\right.$ to $\left.25^{\circ} \mathrm{N}, \mathrm{S}\right)$ shores. Standard error bars are shown. Note break in vertical logarithmic axis

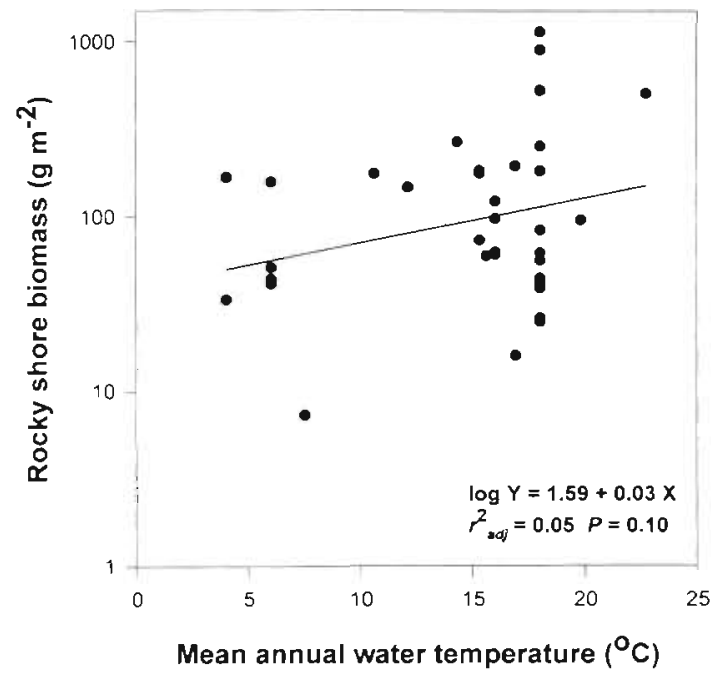

Fig. 3. Relationship between mean annual water temperature and macroinvertebrate biomass on rocky shores

\section{Sedimentary shores}

On sedimentary shores, total macroinvertebrate biomass does not vary significantly with mean annual air and water temperature variables. Nevertheless, water temperature has a negative effect on the biomass of grazers $\left(\mathrm{r}^{2}{ }_{\text {adj }}=0.17, \mathrm{p}=0.011\right)$, suspension feeders $\left(\mathrm{r}^{2}{ }_{\text {adj }}\right.$ $=0.06, p=0.028)$, and carnivores $\left(r^{2}\right.$ adj $=0.08, p=$ 0.009 ), but has no detectable effect on deposit-feeder biomass, which normally accounts for a third of the total biomass. Total biomass increases with wave height at exposed sites, but varies inversely with wave exposure for sedimentary shores in general (Fig. 6)

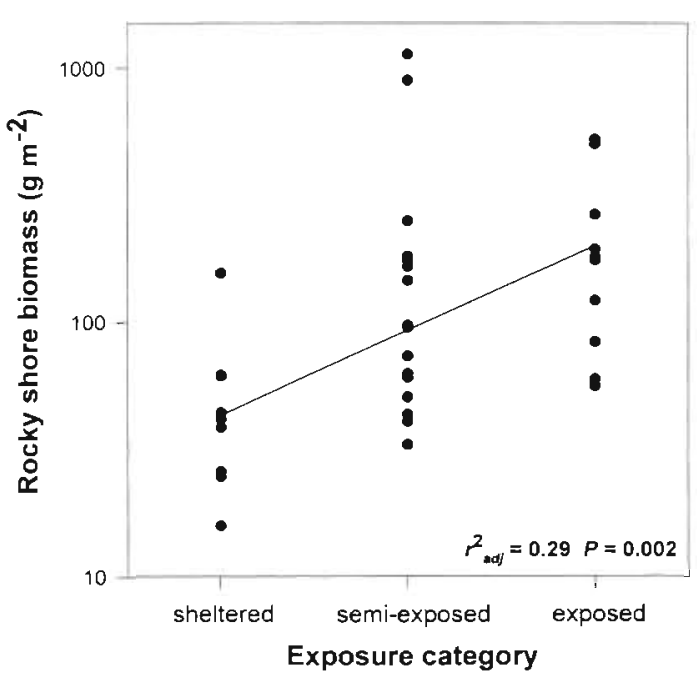

Fig. 4. Relationship between the degree of wave exposure and macroinvertebrate biomass on rocky shores 
because of the high abundances of deposit feeders and carnivores at sheltered sites (Fig. 7). Total biomass is highest on flat beaches (Fig. 6), again reflecting a high abundance of deposit feeders. Grazer biomass follows an opposite pattern by increasing with beach slope (Fig. 8).

Tide range has a weak negative influence on suspension-feeder biomass $\left(\mathrm{r}^{2}{ }_{\text {adj }}=0.07, \mathrm{p}=0.02\right)$ and $\mathrm{a}$ positive influence on deposit-feeder biomass $\left(\mathrm{r}^{2}{ }_{\text {ad }}=\right.$ $0.13, p=0.002)$. These effects are most pronounced at sheltered sites $\left(r^{2}{ }_{\text {adj }}=0.25, p=0.001\right.$ for suspension feeders; $r^{2}$ adj $=0.19, p=0.004$ for deposit feeders). Tide range has a positive effect on carnivore biomass only on exposed shores $\left(r^{2}{ }_{\text {adj }}=0.10, p=0.046\right)$, while tide type has no detectable effect on any functional feeding guild.

The effect of grain size is greater than that of any other variable. The relationship between total biomass and mean grain size is curvilinear (Fig. 6), with biomass reaching peak levels on mudflats ( $>5 \phi$ units) and fine-grained sandy beaches ( 2 to $3 \phi$ units $)$, and minimal levels on unstable coarse sands $i<1 \phi$ units $)$. Deposit-feeder biomass increases with decreasing grain size (i.e. increasing $\phi$ values; $r^{2}{ }_{\text {adj }}=0.33, p<$ 0.0001 ), while no significant trends are found for the
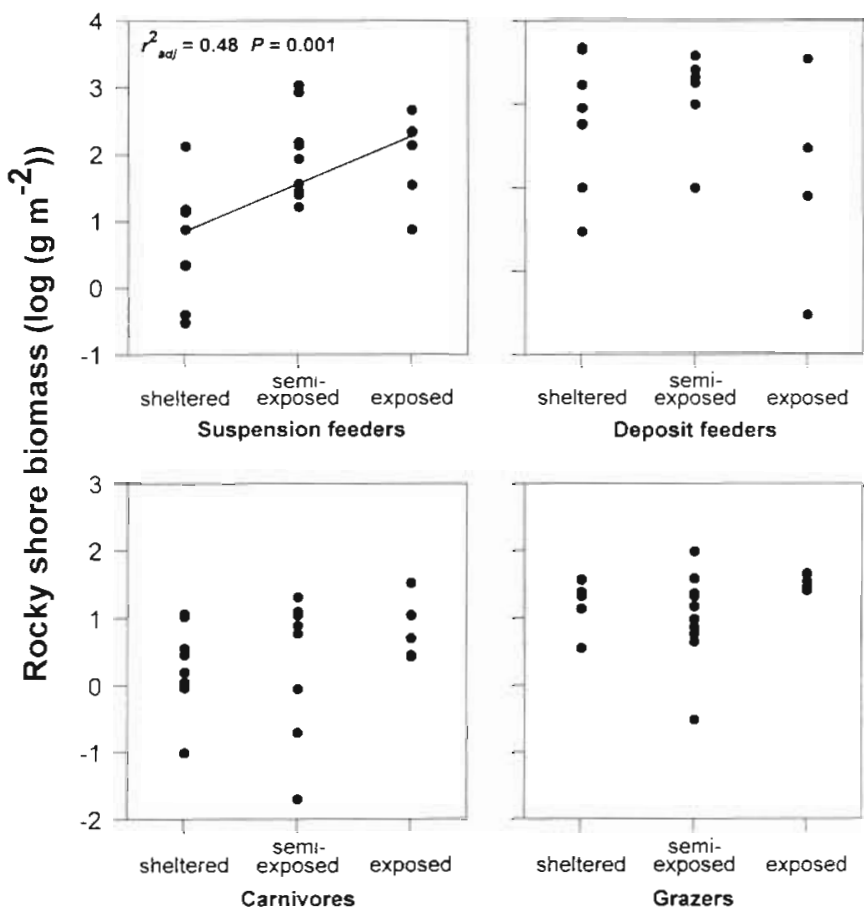

\section{Exposure category}

Fig. 5. Patterns of biomass for different functional feeding guilds in relation to categories of wave exposure on rocky shores. Note that some rocky shores lack deposit feeders or grazers; thus sample sizes vary
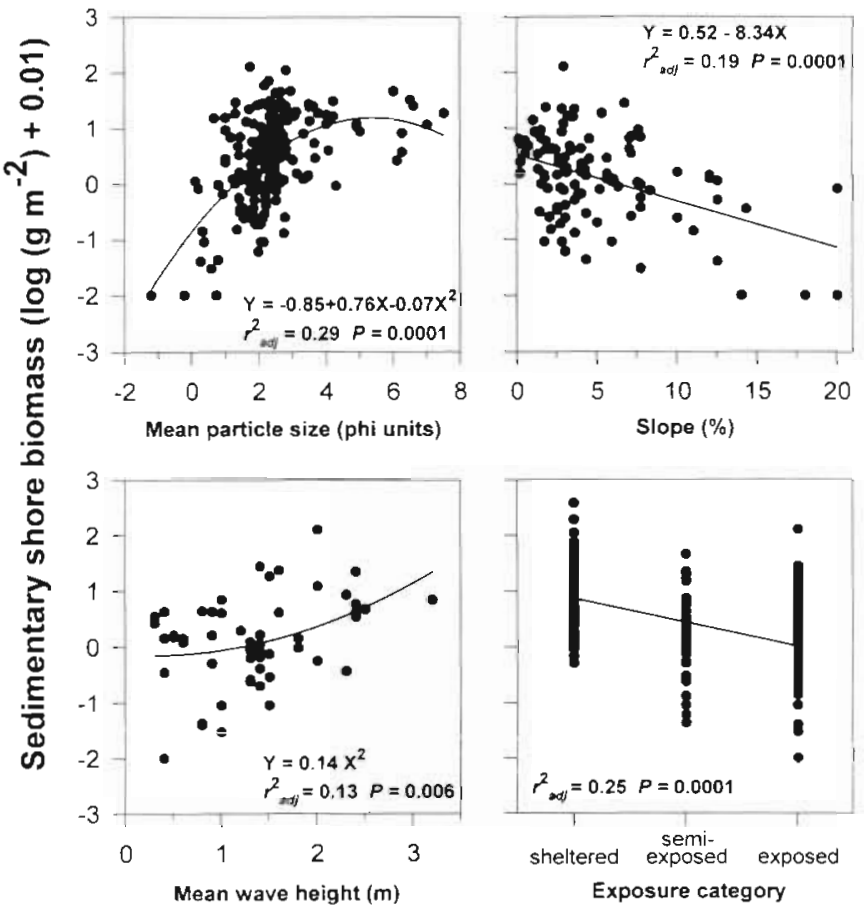

Fig. 6. Relationships between macroinvertebrate biomass and physical variables on sedimentary shores

other functional feeding guilds. Sieve mesh size was not a significant correlate of total biomass nor of any guild except for deposit feeders $\left(\mathrm{r}^{2}{ }_{\mathrm{adj}}=0.24, \mathrm{p}=\right.$ 0.0001 ; ; but even this correlation became insignificant when the effect of covariance with grain size was partialled out

Linear discriminant functions successfully classified 60 to $80 \%$ of shores in which the biomass of the respective functional feeding guild was estimated to be zero (Table 3). The best functions were obtained for carnivores, using tide variables, grain size, and intertidal slope as predictors. Grain size was a significant predictor for every guild except grazers

\section{Multiple regression models}

Multiple regressions explain up to $44 \%$ and $40 \%$ of the variance of total macroinvertebrate biomass on sedimentary and rocky shores, respectively (Tables 4 \& 5). Stepwise regression rejected collinear combinations of variables, often resulting in models composed of only 2 or 3 predictors; thus, independent variables that were significant in simple regressions were sometimes rejected as redundant predictors in multiple regressions. Tables $4 \& 5$ list the best multiple regression models obtained for sedimentary and rocky shores. For sedimentary shore data, grain size accounts 

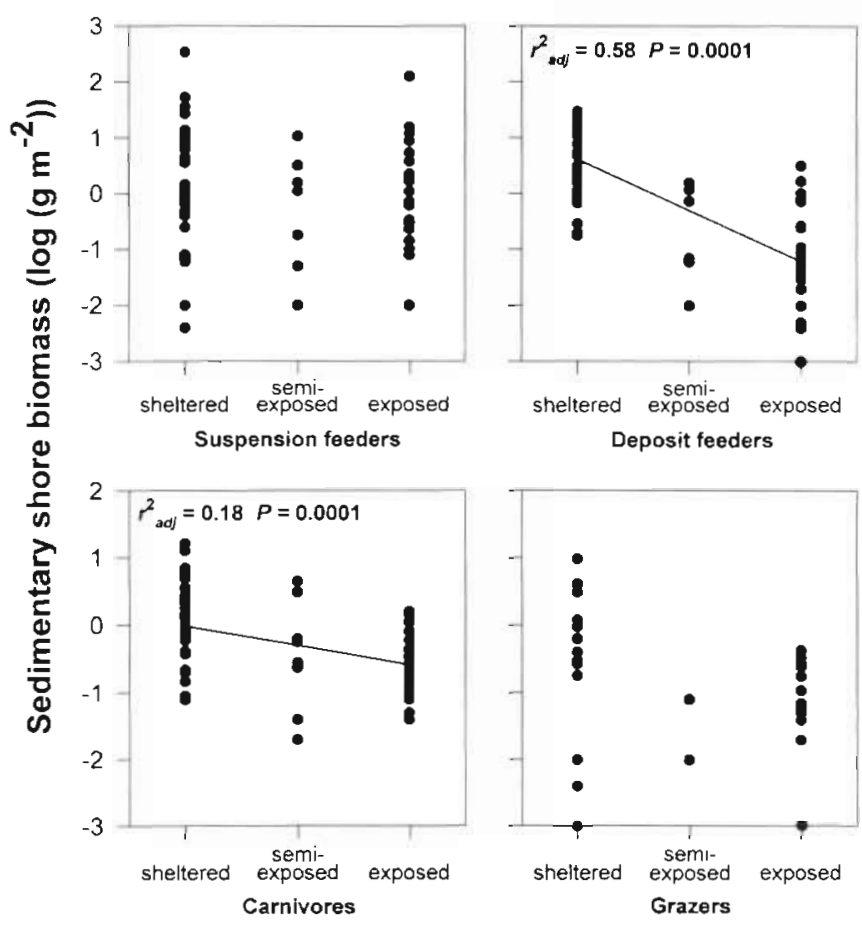

Exposure category

Fig. 7 Patterns of biomass for different functional feeding guilds in relation to categories of wave exposure on sedimentary shores

for about a third of the variance in total biomass more than that explained by exposure, wave height, and tide variables combined. For rocky shore data, a combination of water temperature and wave exposure variables explains a significant fraction of the variance in total biomass.

Methodological variables are insignificant in this analysis. Sieve mesh size was consistently rejected as a
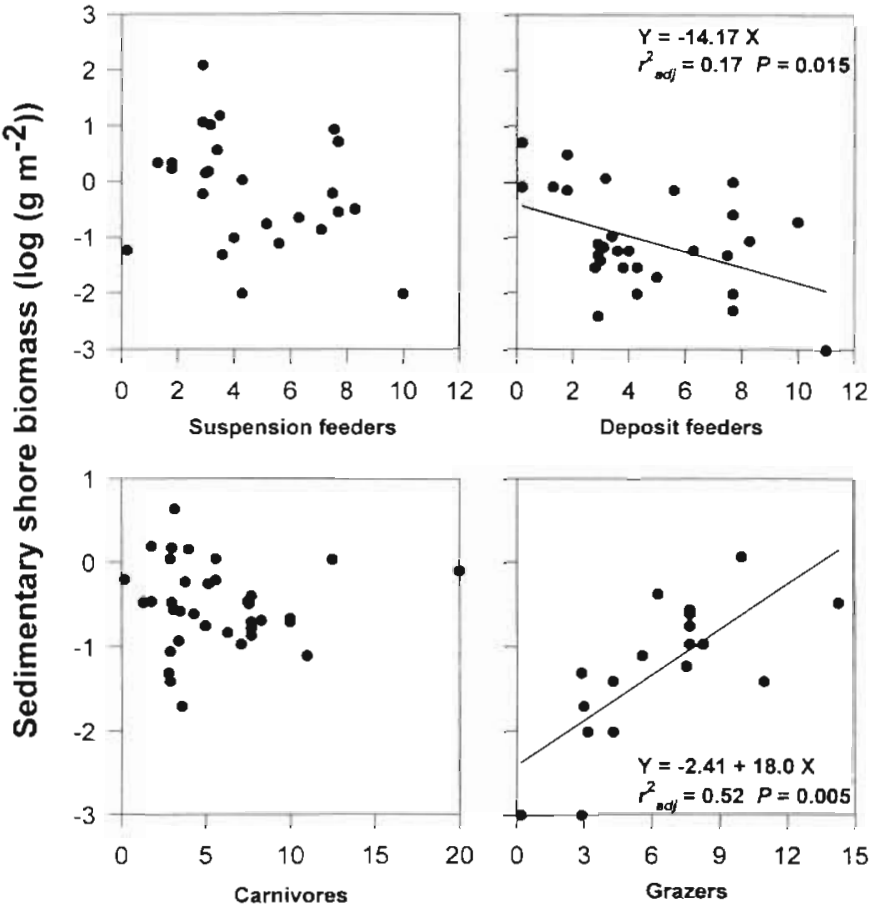

Intertidal slope (\%)

Fig. 8. Patterns of biomass for different functional feeding guilds in relation to tide range on sedimentary shores

predictor in all stepwise models in which grain size is tested. The categorical variable distinguishing annual and summer mean biomass estimates was rejected as a predictor in all sedimentary and rocky shore models.

Multiple regression models also highlight the disparate influences of various physical factors on sedimentary and rocky shore functional feeding guilds. Variation in deposit-feeder biomass on sedimentary

Table 3. Discriminant functions (D1, D2) that classify sedimentary shores with and without functional feeding guilds on the basis of site characteristics. Coefficients for each predictor variable are shown as table entries. The feeding guild is predicted to be absent (i.e. biomass $=0$ ) if D1 $>$ D2, and present (biomass $>0$ ) if D1 $<$ D2. The number of sites classified correctly by each function is presented

\begin{tabular}{|c|c|c|c|c|c|c|c|c|}
\hline & \multicolumn{2}{|c|}{ Suspension feeders } & \multicolumn{2}{|c|}{ Deposit feeders } & \multicolumn{2}{|c|}{ Grazers } & \multicolumn{2}{|c|}{ Carnivores } \\
\hline & D1 & D2 & D1 & D2 & D1 & $\mathrm{D} 2$ & D1 & D2 \\
\hline Constant & -4.770 & -6.583 & -0.427 & -6.621 & -2.089 & -1.125 & -14.405 & -8.200 \\
\hline Grain size $\left(-\log _{2} m m\right)$ & 1.935 & 5.791 & 1.804 & 5.367 & - & - & -6.092 & -0.552 \\
\hline Grain size $\left(-\log _{2} m m\right)^{2}$ & -0.215 & -0.790 & -0.249 & -0.670 & - & - & - & - \\
\hline Intertidal slope $(\%)$ & - & - & - & - & - & - & -16.208 & -9.168 \\
\hline Tide range $(\mathrm{m})$ & - & - & - & - & 1.602 & 1.176 & 3.088 & 2,424 \\
\hline Tide type & - & - & - & - & - & - & 17.571 & 6.379 \\
\hline Air temperature $\left({ }^{\circ} \mathrm{C}\right)$ & 0.411 & 0.265 & 0.400 & 0.286 & - & - & - & - \\
\hline Correct classifications & $11 / 18$ & $49 / 57$ & $9 / 15$ & $55 / 59$ & $24 / 30$ & $25 / 48$ & $5 / 8$ & $33 / 33$ \\
\hline Wilks' lambda & \multicolumn{2}{|c|}{0.654} & \multicolumn{2}{|c|}{0.683} & \multicolumn{2}{|c|}{0.932} & \multicolumn{2}{|c|}{0.490} \\
\hline $\mathrm{p}$ & \multicolumn{2}{|c|}{0.0001} & \multicolumn{2}{|c|}{0.0001} & \multicolumn{2}{|c|}{0.0001} & \multicolumn{2}{|c|}{0.0001} \\
\hline
\end{tabular}


Table 4. Best multiple regression models for predicting sedimentary shore macroinvertebrate biomass [ $\left.\log _{10}\left(g \mathrm{AFDW}^{-2}\right)\right]$ for the entire community (Total) and principal functional feeding guilds. Recression coefficients for each predictor variable are shown as table entries. Numbers in parentheses are standard errors (SE) for the coefficients. -: not tested; ns: tested but not significant ${ }^{*} p<0.10, \cdot p<0.05, \cdots p<0.01, \cdots p<0.001$

\begin{tabular}{|c|c|c|c|c|c|}
\hline & Total & Suspension feeders & Deposit feeders & Grazers & Carnivores \\
\hline Intercept & ns & $1.36(0.44)^{\cdots}$ & ns & $-2.41(0.30)^{\cdots}$ & ns \\
\hline Grain size $\left(-\log _{2} \mathrm{~mm}\right)$ & $0.68(0.11)^{\cdots}$ & ns & $0.19(0.11)^{\mathrm{d}}$ & ns & ns \\
\hline Grain size $\left(-\log _{2} \mathrm{~mm}\right)^{2}$ & $-0.07(0.01)^{\cdots}$ & ns & ns & ns & ns \\
\hline Intertidal slope (\%) & - & - & - & $18.0(4.1)^{\cdots}$ & - \\
\hline Exposure (EXP1) & $-0.54(0.11) \cdots$ & ns & $-1.20(0.34)^{\cdots}$ & ns & $-0.37(0.21)^{a}$ \\
\hline Exposure (EXP2) & $-0.46(0.11)^{\cdots}$ & ns & $-1.52(0.22) \cdots$ & ns & $-0.52(0.14)^{\cdots}$ \\
\hline Tide range $(\mathrm{m})$ & $-0.09(0.02) \cdots$ & $-0.22(0.09)^{\circ}$ & $0.16(0.07)^{\prime}$ & ns & ns \\
\hline Tide type & $-0.92(0.25) \cdots$ & ns & ns & ns & ns \\
\hline Water temperature $\left({ }^{\circ} \mathrm{C}\right)$ & ns & $-0.5(0.02)^{\bullet}$ & ns & ns & $-0.02(0.01)^{\mathrm{a}}$ \\
\hline$R^{2}{ }_{d d 1}$ & 0.444 & 0.173 & 0.671 & 0.517 & 0.210 \\
\hline$p$ & $<0.0001$ & 0.0075 & $<0.0001$ & 0.0005 & 0.0002 \\
\hline SE of estimate & 0.578 & 0.913 & 0.669 & 0.545 & 0.543 \\
\hline $\mathrm{N}$ & 204 & 54 & 58 & 18 & 75 \\
\hline
\end{tabular}

shores is well predicted by a combination of wave exposure, grain size and tide range $\left(R_{\text {adj }}^{2}=0.67, \mathrm{p}=\right.$ $0.0001)$, while no significant models can be derived for deposit feeders on rocky shores. Wave exposure explains $44 \%$ of the variation in suspension feeder biomass on rocky shores, but has no general predictive value for suspension feeders on sedimentary shores. Conversely, wave exposure does not predict carnivore biomass on rocky shores, but is correlated negatively with carnivore biomass on sedimentary shores (Figs. 5 $\& 7$ ). The average amount of variation in functional feeding guild biomass explained by multiple regression models is $39 \%$ for sedimentary shores and $24 \%$ for rocky shores.

\section{DISCUSSION}

\section{Latitudinal patterns of intertidal biomass}

Maximal biomass values on temperate shores (Fig. 1) may be the net result of limiting factors in polar and tropical regions, including the relatively high abundance and diversity of mobile predators in the tropics (Bertness et al. 1981, Menge \& Lubchenco 1981, Lubchenco et al. 1984, Garrity et al. 1986) and freezing temperatures and ice disturbance at high latitudes (Bourget et al. 1985, Bergeron \& Bourget 1986, Pugh \& Davenport 1997). However, during ice-free seasons, even arctic shores can support biomass levels that are at least as great as those of tropical shores (Fig. 1; Ellis 1960, Zenkevitch 1963). Tropical shores (reviewed by Alongi 1990) are also subject to intense climatic disturbance, severe desiccation stress, variable salinity regimes, hypoxic waters, and intensely heated sands (exceeding $50^{\circ} \mathrm{C} ;$ Dexter 1979 ).
Furthermore, primary planktonic production appears to be transfered to higher trophic levels less efficiently at warmer latitudes (Petersen \& Curtis 1980). Less phytoplankton production may reach tropical benthos because it is continuous and in phase with zooplankton production (Levinton 1982, Banse \& English 1994). By contrast, phytoplankton production in temperate regions is highly seasonal and a larger amount may escape pelagic herbivores and thus become available for benthic consumption, particularly by suspension feeders (Fig. 2). The biomass of temperate shore communities is also enhanced by inputs of organic detritus from kelp beds, particularly in winter when phytoplankton production is low (Duggins et al. 1989, Bustamante \& Branch 1996b).

\section{Influence of temperature and tide variables}

In the multiple regression model for rocky shores (Table 5), mean annual water temperature is a significant predictor of the total macroinvertebrate biomass, and the best single predictor of grazer biomass. Some low biomass values associated with mean annual water temperatures $<10^{\circ} \mathrm{C}$ (Fig. 3) may represent, at least in part, disturbance due to ice scour (e.g. at St. Lawrence River estuary sites; Bergeron \& Bourget 1986). The inverse correlation between carnivore biomass and tide range $\left(\mathrm{r}^{2}{ }_{\mathrm{adj}}=0.16, \mathrm{p}=0.039\right)$ may reflect the environmental stress that a wide intertidal zone places on predators which cannot easily escape to a subtidal refuge.

On sedimentary shores, by contrast, water temperature has a negative effect on the biomass of grazers, suspension feeders, and carnivores. For grazers, the best multiple regression model obtained was based 
Table 5. Best multiple regression models for predicting rocky shore macroinvertebrate biomass $\left[\log _{10}\left(\mathrm{~g} \mathrm{AFDW} \mathrm{m}^{-2}\right)\right]$ for the entire community (Total) and principal functional feeding guilds (no significant models were obtained for deposit feeders). Regression coefficients for each predictor variable are shown as table entries. Numbers in parentheses are standard errors (SE) for the coefficients. ns: tested but not significant; ${ }^{d} p<0.10,{ }^{\circ} p<0.05,{ }^{\prime} p<0.01, \cdots p<0.001$

\begin{tabular}{|c|c|c|c|c|}
\hline & Total & Suspension feeders & Grazers & Carnivores \\
\hline Intercept & $1.21(0.19)^{\cdots}$ & $0.64(0.25)^{\bullet}$ & $0.66(0.29)^{\circ}$ & $1.25(0.40)^{\cdots}$ \\
\hline Exposure (EXP1) & $0.62(0.16)^{\cdots}$ & $1.39(0.34)^{\cdots}$ & ns & ns \\
\hline Exposure (EXP2) & $0.61(0.17)^{\cdots}$ & $1.35(0.39)^{\cdots}$ & ns & ns \\
\hline Tide range $(\mathrm{m})$ & ns & ns & ns & $-0.36(0.16)^{*}$ \\
\hline Tide type & ns & ns & ns & ns \\
\hline Water temperature $\left({ }^{\circ} \mathrm{C}\right)$ & ns & ns & $0.04(0.02)^{\mathrm{d}}$ & ns \\
\hline Water temperature $\left({ }^{\circ} \mathrm{C}\right)^{2}$ & $0.001(0.001)^{*}$ & ns & ns & ns \\
\hline $\mathrm{R}_{\text {adj }}^{2}$ & 0.400 & 0.435 & 0.119 & 0.163 \\
\hline $\mathrm{p}$ & 0.0004 & 0.001 & 0.0596 & 0.0395 \\
\hline SE of estimate & 0.374 & 0.715 & 0.532 & 0.742 \\
\hline $\mathrm{N}$ & 36 & 24 & 23 & 21 \\
\hline
\end{tabular}

exclusively on intertidal slope (Table 4). The next best model was based solely on a negative correlation with mean annual water temperature $\left(\mathrm{r}_{a d j}^{2}=0.18, \mathrm{p}=\right.$ 0.011). Deposit-feeder biomass appears unrelated to both mean annual temperature variables. In multiple regression models, tide range has opposing effects on suspension feeders and deposit feeders. When the data are stratified according to degree of wave exposure, tide range shows significant effects only at sheltered sites, where it is correlated negatively with suspension-feeder biomass $\left(\mathrm{r}^{2}{ }_{\text {ad }}=0.25, \mathrm{p}=0.001\right)$ and positively with deposit-feeder biomass $\left(\mathrm{r}^{2}{ }_{\text {adj }}=0.19, \mathrm{p}=\right.$ 0.004); these trends support the generalization that tidal currents are the major supplier of nutrients, food, and larvae to sheltered marine habitats but can also raise concentrations of suspended solids and flocculant material high enough to inhibit active suspension feeders (Leonard et al. 1998).

\section{Influence of sedimentary shore morphology: grain size and intertidal slope}

The negative relationship between slope and biomass occurs over a wide range of beach types and tidal regimes (Fig 6) and can be explained by 2 factors, wave energy and shore stability. The slope of a sedimentary shore determines how much wave energy is dissipated on intertidal sands. Reflective beaches have steep faces and coarse sands, and reflect wave energy back to sea. Dissipative beaches have flat slopes and fine-grained sands, and are subject to heavy wave action whose energy is dissipated over the intertidal zone (Brown \& McLachlan 1990). Macroinvertebrate biomass tends to be higher on dissipative beaches (McLachlan 1990, McLachlan et al. 1993), whose swash climates allow greater retention of organic par- ticles for suspension feeders and deposit feeders (Talbot \& Bate 1989).

The second important factor, shore stability, is the capacity of a shore to resist morphological variation due to wave or tidal disturbance. Coarse-grain beaches tend to be too unstable to support dense macroinvertebrate populations (Eleftheriou \& Nicholson 1975, Dexter 1976, 1988, McLachlan 1985b, Allan \& Moore 1987 , Jaramillo \& McLachlan 1993). Overall, intertidal biomass is greatest on rocky shores (generally, -11 to $-6 \phi$ units, depending on the proportions of sand, gravel, and boulders), but declines precipitously to nearly negligible values on gravel beaches $(-1$ to $1 \phi$ units $)$, and then increases with progressively smaller grain sizes toward compact fine sands and mudflats (Fig. 6). Discriminant function analysis predicts the absence of suspension feeders, deposit feeders, and carnivores on shores with large grain sizes ( $<1 \phi$ units), and intertidal slope is the major threshold factor for grazers (Table 3 ). Therefore, human activities that reduce the stability of sedimentary shores, such as beach sand harvesting (which causes intertidal recession; Carter et al. 1992) and the disposal of mine tailings (which increases sediment size and beach slope; McLachlan 1996), may cause substantial reductions in the biomass and trophic composition of resident macrofauna.

\section{Influence of wave exposure}

Because there is no widely used method of measuring spatial variation in wave exposure, our synthesis of literature data required that we use a simple discrete variable to compare sites. Thus, our classification is somewhat subjective and does not distinguish between exposed sites with different wave fetches. Nevertheless, a few strong patterns emerge. Total biomass 
is higher on exposed (rather than on sheltered) rocky shores, due mostly to dense populations of suspensionfeeding mussels, barnacles, and ascidians (Figs. 4 \& 5). The opposite trend is observed for sedimentary shores (Fig. 6), supporting the broad generality of regional observations in Scotland, South Africa, and Chile (Eleftheriou \& Nicholson 1975, Eleftheriou \& McIntyre 1976, McQuaid \& Branch 1984, 1985, Jaramillo \& McLachlan 1993, Bustamante et al. 1995, Bustamante \& Branch 1996a). Macroinvertebrate biomass on sheltered rocky shores, where macroalgal standing stocks may be large, tends to be dominated by grazers (Dayton 1971, McQuaid \& Branch 1984, 1985, Bustamante \& Branch 1996a, Ingólfsson 1996, unpubl. data). On sheltered sedimentary shores, a rich microflora is often present (Broom 1982, McLachlan 1983, Reise 1985, Schwinghamer et al. 1986, Kristensen 1993) and deposit feeders and carnivores/scavengers reach their maximum biomass (Fig. 7).

Increased exposure to wave action results in increased food availability and feeding time for suspension feeders (Fréchette \& Bourget 1985), which demonstrate higher growth potential on exposed versus sheltered rocky shores (Bertness et al. 1991, Dahlhoff \& Menge 1996). Indeed, mussel beds on exposed rocky shores have been shown to be as productive as rainforests (Leigh et al. 1987). As a result of the extraordinary abundance and growth of sessile suspension feeders, macroinvertebrate biomass on temperate rocky shores (Table 2 ) reaches peak values that are 10 to 100 times higher than those recorded in subtidal (non-Antarctic), continental slope, and deep-sea benthic environments (Zenkevitch 1963, Alongi 1990, Brey \& Gerdes 1997).

Field experiments have shown mobile predators and grazers to be less efficient at foraging on exposed rocky shores (Lubchenco \& Menge 1978, Menge 1978 , Peterson 1979, Burrows \& Hughes 1989), unless they have access to refugia provided by surface heterogeneity (Gosselin \& Bourget 1989). Thus, environmental stress models of community structure (Menge \& Sutherland 1987, Menge \& Olson 1990) predict that mobile consumers (carnivores/scavengers and grazers) will be limited by high wave exposure. However, our data show no evidence of carnivore and grazer biomass limitation on exposed rocky shores (Fig. 5). Conversely, carnivore biomass is reduced on exposed sedimentary shores (Fig. 7), due possibly to a greater susceptibility to wave stress.

\section{Why do suspension feeders dominate rocky shores?}

To address the question of why suspension feeders tend to dominate the world's rocky shores, we must consider the sources of food available to the various functional feeding guilcs. Suspension feeders exploit diverse particulate food resources (phytoplankton, detritus, bacteria, dissolved organic matter) produced in a 3-dimensional pelagic environment and replenished by wave action and tidal currents that flow over attached and sedentary animals (Fréchette \& Bourget 1985, Gili \& Coma 1998). By contrast, except for periodic strandings of macroalgal debris (McLachlan 1985b, Bustamante \& Branch 1996b), the food of grazers is produced in relatively limited 2-dimensional space in situ. Accordingly, a study of South African rocky shores by Bustamante et al. (1995) found that suspension-feeder biomass was correlated with nearshore primary planktonic production while the biomass of grazers was correlated with intertidal benthic algal production. Broad access to diverse food sources, combined with relatively low energetic cost of food capture for sessile organisms, suggests that the success of benthic suspension feeders is related, at least in part, to optimal foraging (Riisgård \& Larsen 1995, Gili \& Coma 1998).

The somatic growth of suspension feeders on rocky shores has been shown to be limited by nearshore phytoplankton concentration (Bertness et al. 1991. Fréchette \& Grant 1991, Jahlhoff \& Menge 1996, Loo \& Rosenberg 1996) and the influx of kelp-derived organic matter (Duggins et al. 1989). Similarly, high inputs of particulate organic matter (e.g. from surf diatom blooms, or advection from upwelling zones) are correlated with high suspension-feeder biomass on sandy beaches (McLachlan 1983). As suspension feeders are dominant components of intertidal systems and often support a rich associated fauna (Fielding et al. 1994, Seed 1996, Mckindsey \& Bourget unpubl.), nearshore primary production may be a useful predictor of intertidal biomass over large geographic scales if data of sufficient spatial resolution are available (Bustamante et al. 1995, Menge et al. 1997).

\section{CONCLUSIONS}

Our analysis identifies several patterns along latitudinal, hydrodynamic, and climatic gradients. While the heterogeneity of our data obviously reduces precision in the regression models, highly significant trends observed for grain size, wave height, exposure, shore slope, tide and temperature variables demonstrate the strong influence of these physical factors on intertidal macroinvertebrate biomass. Wave exposure appears to be a factor of universal importance in limiting intertidal biomass; this is not surprising given that exposure combined with wave energy determines sedimentary shore profiles and stability, affects sediment charac- 
teristics (texture, organic content, oxygen content of interstitial water), delivers food resources and larvae, and can mediate biological interactions (predation, competition, commensalism) (Fréchette \& Bourget 1985, Menge \& Farrell 1989, Talbot \& Bate 1989, Brown \& McLachlan 1990).

Community composition and abundance on intertidal rocky shores is traditionally viewed as the outcome of biological interactions, modified by environmental stressors (Dayton 1971, Paine 1974, Connell 1975, Peterson 1979, Menge \& Farrell 1989, and others). Although the scarcity of published biomass estimates for rocky shores limits statistical power, the significant amount of variance explained by our models supports the broad validity of the concept of the rocky shore as an environment in which secondary production is strongly influenced by climatic and hydrodynamic factors. Conversely, exposed sedimentary shores are assumed to be physically controlled systems where biological interactions have negligible influence on community structure (McLachlan et al. 1983, Brown \& McLachlan 1990, Dexter 1992). The generality of this paradigm has been challenged (Defeo et al. 1997), and the large residual variance for sedimentary shores in our models may partly reflect the importance of predation in regulating macroinvertebrate biomass (Baird et al. 1985, Moller 1986).

The substantial contribution to intertidal biomass by suspension feeders suggests that further precision in our empirical models would likely be obtained by accounting for spatial differences in nearshore primary productivity. Factors that influence the delivery of organic matter and nutrients to intertidal shores (e.g. wave energy and periodicity; coastal upwelling) may also prove to be important predictors of biomass (Bosman et al. 1987, Leigh et al. 1987). However, any major improvements in precision will require additional comparable data which are not presently available in the literature. The relative paucity of community biomass data for rocky shores is surprising given the popularity of these environments for ecological experimentation. More data are required, particularly for tropical rocky shores, to make further generalizations about organismal abundance in intertidal systems. Therefore, we strongly encourage researchers to make raw data broadly accessible, e.g. by placing them on Internet websites. This practice would help pave the way for statistical syntheses to identify other global trends and test the generality of theories in marine ecology.

Acknowledgements. We are grateful to A. Ingólfsson for sharing unpublished data on Icelandic shores, and P. Archambault for information on St. Lawrence River estuary sites. We also thank L. E. Johnson, H. M. Reiswig, and C. McKindsey for thoughtful comments on the manuscript. This work was funded by a postdoctoral fellowship to A.R. from the Natural Sciences and Engineering Research Council of Canada.

\section{LITERATURE CITED}

Allen PL, Moore JJ (1987) Invertebrate macrofauna as potential indicators of sandy beach instability. Estuar Coast Shelf Sci 24:109-125

Alongi DM (1990) The ecology of tropical soft-bottom benthic ecosystems. Oceanogr Mar Biol Annu Rev 28:381-496

Ansell AD, McLusky DS, Stirling A, Trevallion A (1978) Production and energy flow in the macrobenthos of two sandy beaches in South West India. Proc R Soc Edinb B 76: $269-296$

Archambault P, Bourget E (1996) Scales of coastal heterogeneity and benthic intertidal species richness, diversity and abundance. Mar Ecol Prog Ser 136:111-121

Arias AM, Drake P (1994) Structure and production of the benthic macroinvertebrate community in a shallow lagoon in the Bay of Cádiz. Mar Ecol Prog Ser 115:151-167

Bachelet G, de Montaudouin X, Dauvin JC (1996) The quantitative distribution of subtidal macrozoobenthic assemblages in Arcachon Bay in relation to environmental factors: a multivariate analysis. Estuar Coast Shelf Sci 42 : $371-391$

Baird D, Evans PR, Mile H, Pienkowski MW (1985) Utilization by shorebirds of benthic invertebrate production in intertidal areas. Oceanogr Mar Biol Annu Rev 23:573-597

Bally R (1983) Intertidal zonation on sandy beaches of the west coast of South Africa. Cah Biol Mar 24:85-103

Bally R (1987) The ecology of sandy beaches of the Benguela ecosystem. S Afr J Mar Sci 5:759-770

Banse K, English DC (1994) Seasonality of coastal zone color scanner phytoplankton pigment in the offshore oceans. J Geophys Res 99(C4):7323-7345

Barnes RD (1986) Invertebrate zoology, 5th edn. Saunders College, Philadelphia

Batzli GO (1969) Distribution of biomass in rocky intertidal communities on the Pacific coast of the United States. J Anim Ecol 38:531-549

Bergeron P, Bourget E (1986) Shore topography and spatial partitioning of crevice refuges by sessile epibenthos in an ice disturbed environment. Mar Ecol Prog Ser 28:129-145

Bertness MD, Garrity SD, Levings SC (1981) Predation pressure and gastropod foraging: a tropical-temperate comparison. Evolution 35:995-1007

Bertness MD, Gaines SD, Bermudez D, Sanford E (1991) Extreme spatial variation in the growth and reproductive output of the acorn barnacle Semibalanus balanoides. Mar Ecol Prog Ser 75:91-100

Beukema JJ (1974) Seasonal changes in the biomass of the macro-benthos of a tidal flat area in the Dutch Wadden Sea. Neth J Sea Res 8:94-107

Bloom SA, Simon JL, Hunter VD (1972) Animal-sediment relations and community analysis of a Florida estuary. Mar Biol 13:43-56

Bosman AL, Hockey PAR, Siegfried WR (1987) The influence of coastal upwelling on the functional structure of rocky intertidal communities. Oecologia 72:226-232

Bourget E, Messier D (1983) Macrobenthic density, biomass, and fauna of intertidal and subtidal sand in a Magdalen Islands lagoon, Gulf of St Lawrence, Can J Zool 61: 2509-2518

Bourget E, Archambault D, Bergeron P (1985) Effet des propriétés hivernales sur les peuplements épibenthiques 
intertidaux dans un milieu subarctique, l'estuaire du Saint-Laurent. Nat Can (Rev Écol Syst) 112:131-142

Brey $T$, Gerdes D (1997) Is Antarctic benthic biomass really higher than elsewhere? Antarct Sci 9:266-267

Broom MJ (1982) Structure and seasonality in a Malaysian mudflat community. Estuar Coast Shelf Sci 15:135-150

Brown AC, McLachlan A (1990) Ecology of sandy shores. Elsevier, Amsterdam

Brown JH (1995) Macroecology. University of Chicago Press, Chicago

Burrows MT, Hughes RN (1989) Natural foraging of the dogwhelk, Nucella lapillus (Linnaeus): the whether and weather to feed. J Mollusc Stud 55:285-295

Bustamante RH, Branch GM (1996a) Large-scale patterns and trophic structure of southern African rocky shores: the roles of geographic variation and wave exposure. J Biogeogr 23:339-351

Bustamante RH, Branch GM (1996b) The dependence of intertidal consumers on kelp-derived organic matter on the west coast of South Africa. J Exp Mar Biol Ecol 196: $1-28$

Dustamintc RH, Branch GM, Eekhout S, Robertson R, Znutendyk P, Schleyer M, Dye A, Hanekom N, Keats D, Jurd M, McQuaid C (1995) Gradients of intertidal primary productivity around the coast of South Africa and their relationships with consumer biomass. Ocecologia 102 . $189-201$

Carter RWG, Eastwood DA, Bradshaw P (1992) Small scale sediment removal from beaches in Northern Ireland: environmental impact, community perception and conservation management. Aquat Conserv 2:95-113

Connell JH (1975) Some mechanisms producing structure in natural communities: a model and evidence from field experiments. In: Cody ML, Diamond JM (eds) Ecology and evolution of communities. Belknap Press of Harvard University, Cambridge, MA, p 460-490

Crisp DJ (1984) Energy flow measurement. In: Holme NA McIntyre $A D$ (eds) Methods for the study of marine benthos. Blackwell, Oxford, p 284-372

Croker RA, Hager RP, Scott KJ (1975) Macroinfauna of northern New England marine sand. II. Amphipod-dominated intertidal communities. Can J Zool 53:42-51

Currie DJ, Fritz JT (1993) Global patterns of animal abundance and species energy use. Oikos 67:56-68

Dahlhoff EP, Menge BA (1996) Influence of phytoplankton concentration and wave exposure on the ecophysiology of Mytilus californianus. Mar Ecol Prog Ser 144:97-107

Dayton PK (1971) Competition, disturbance, and community organisation: the provision and subsequent utilization of space in a rocky intertidal community. Ecol Monogr 41 . $351-389$

Dayton PK (1984) Processes structuring some marine communities: are they general? In: Strong DR, Simberloff $D$, Abele L, Thistle AB (eds) Ecological communities: conceptual issues and the evidence. Princeton University Press, Princeton, p $181-197$

Defeo O, Jaramillo E, Lyonnet A (1992) Community structure and intertidal zonation of the macroinfauna on the Atlantic Coast of Uruguay. J Coast Res 8:830-839

Defeo O, Brazeiro A, de Alava A, Riestra G (1997) Is sandy beach macrofauna only physically controlled? Role of substrate and competition in isopods. Estuar Coast Shelf Sci 45:453-462

DeLancey LB (1989) Trophic relationship in the surf zone during the summer at Folly Beach, South Carolina. J Coast Res 5:477-488

Dewarumez JM, Davoult D, Frontier S (1991) Examples of responses of benthic communities to environmental stress (Dover Strait, France). Oceanol Acta 11:191-196

Dexter DM (1972) Comparison of the community structures in a Pacific and an Atlantic Panamanian sandy beach. Bull Mar Sci 22:449-462

Dexter DM (1976) The sandy-beach fauna of Mexico. Southwest Nat 20:479-485

Dexter DM (1979) Community structure and seasonal variation in intertidal Panamanian sandy beaches. Estuar Coast Mar Sci 9:543-558

Dexter DM (1988) The sandy beach fauna of Portugal. Arq Mus Bocage 1:101-110

Dexter DM (1992) Sandy beach community structure: the role of exposure and latitude. J Biogeogr 19:59-66

Donn TE Jr, Cockcroft AC (1989) Macrofaunal community structure and zonation of two sandy beaches on the central Namib coast, South West Africa/Namibia. Madoqua 16:129-135

Downing JA (1979) Aggregation, transformation, and the design of benthos sampling programs. J Fish Res Board Can 36:1454-1463

Duggins DO, Simenstad CA, Estes JA (1989) Magnification of secondary production by kelp detritus in coastal marine ecosystems. Science 245:170-173

Dye AH, McLachlan A, Wooldridge T (1981) The ecology of sand beaches in Natal. S Afr J Zool 16:200-209

Edgar GJ, Shaw C (1995) The production and trophic ecology of shallow-water fish assemblages in southern Australia. II. Diets of fishes and trophic relationships between fishes and benthos at Western Port, Victoria. J Exp Mar Biol Ecol 194:83-106

Edwards RRC (1973) Production ecology of two Caribbean marine ecosystems. I. Physical environment and fauna. Estuar Coast Mar Sci 1:303-318

Eleftheriou A, Jones DA (1976) The genus Eurydice on the west coast of India. J Zool 178:385-394

Eleftheriou A, McIntyre AD (1976) The intertidal faund of sandy neaches - a survey of the Scottish Coast. Scot Fish Res Rep 6:1-61

Eleftheriou A, Nicholson MD (1975) The effects of exposure on beach fauna. Cah Biol Mar 16:695-710

Eleftheriou A, Robertson MR (1988) The intertidal fauna of sandy beaches - a survey of the East Scottish Coast. Scot Fish Res Rep 38:1-52

Ellis DV (1960) Marine infaunal benthos in arctic North America. Arct Inst N Am Tech Pap 5:1-53

Erftemeijer P, Swennen C (1990) Densities and biomass of macrobenthic fauna of some intertidal areas in Java Indonesia. Wallaceana 59/60:1-6

FAO (1997) Fishery statistics yearbook: commodities, Vol 81 Food and Agricultural Organization, United Nations, Rome

Fauchald $K_{1}$ Jumars PA (1979) The diet of worms: a study of polychaete feeding guilds. Oceanogr Mar Biol Annu Rev $17: 193-284$

Fielding PJ, Weerts KA, Forbes AT (1994) Macroinvertebrate communities associated with intertidal and subtidal beds of Pyura stolonifera (Heller) (Tunicata: Ascidiacea) on the Natal Coast. S Afr J Zool 29:46-51

Foster MS (1990) Organization of macroalgal assemblages in the Northeast Pacific: the assumption of homogeneity and the illusion of generality. Hydrobiologia 192:21-33

Foster MS, De Vogelaere A.P, Harold C, Pears JS, Thum AB (1988) Causes of spatial and temporal patterns in rocky intertidal communities of central and northern California. Mem Calif Acad Sci 9:1-45

Fréchette $M$, Bourget $E$ (1985) Energy flow between the pelagic and benthic zones: factors controlling particulate 
organic matter available to an intertidal mussel bed. Can J Fish Aquat Sci 42:1158-1165

Fréchette M, Grant J (1991) An in situ estimation of the effect of wind-driven resuspension on the growth of the mussel Mytilus edulis L. J Exp Mar Biol Ecol 148:201-213

Fuji A, Nomura H (1990) Community structure of the rocky shore macrobenthos in southern Hokkaido, Japan. Mar Biol 107:471-477

Garlo EV (1980) Abundance and distribution of benthic macroinvertebrates near Little Egg Inlet, New Jersey from 1972 to 1974. Int Rev Ges Hydrobiol 65:345-356

Garrity SD, Levings SC, Caffey HM (1986) Spatial and temporal variation in shell crushing by fishes on rocky shores of Pacific Panama. J Exp Mar Biol Ecol 103:131-142

Gili JM, Coma R (1998) Benthic suspension feeders: their paramount role in littoral marine food webs. Trends Ecol Evol 13:316-321

Glynn PW (1965) Community composition, structure, and interrelationships in the marine intertidal Endacladia muricata - Balanus glandula association in Monterey Bay, California. Beaufortia 12:143-160

Gorshkov SG (1978) World ocean atlas, Vol I-III. Pergamon, Oxford

Gosselin LA, Bourget E (1989) The performance of an intertidal predator Thais lapillus, in relation to structural heterogeneity. J Anim Ecol 58:287-303

Gray JS, Rieger RN (1971) A quantitative study of the meiofauna of an exposed sandy beach, at Robin Hood's Bay, Yorkshire. J Mar Biol Assoc UK 51:1-19

Hardy MA (1993) Regression with dummy variables. Sage Publications, Newbury Park, CA

Haynes D, Quinn GP (1995) Temporal and spatial variability in community structure of a sandy intertidal beach. Cape Paterson, Victoria, Australia. Mar Freshw Res 46:931-942

Heck KL Jr, Able KW, Roman CT, Fahay MP (1995) Composition, abundance, biomass, and production of macrofauna in a New England estuary: comparisons among eelgrass meadows and other nursery habitats. Estuaries 18: 379-389

Hibbert CJ (1976) Biomass and production of a bivalve community on an intertidal mud-flat. J Exp Mar Biol Ecol 25: 249-261

Holm RF (1978) The community structure of a tropical marine lagoon. Estuar Coast Mar Sci 7:329-345

Hubertz JM, Brooks RM, Brandon WA, Tracy BA (1994) Hindcast wave information for the US Atlantic Coast. J Coast Res 10:79-100

Hughes RN, Gamble JC (1977) A quantitative survey of the biota of intertidal soft substrata on Aldabra Atoll, Indian Ocean. Phil Trans R Soc Lond B 279:327-355

Hughes RN, Thomas MLH (1971) The classification and ordination of shallow-water benthic samples from Prince Edward Island, Canada. J Exp Mar Biol Ecol 7:1-39

Ingólfsson A (1996) The distribution of intertidal macrofauna on the coasts of Iceland in relation to temperature. Sarsia 91:29-44

Iwasaki K (1995) Comparison of mussel bed community between two intertidal mytilids Septifer virgatus and Hormomya mutabilis. Mar Biol 123:109-119

Jaramillo E, McLachlan A (1993) Community and population responses of the macroinfauna to physical factors over a range of exposed sandy beaches in south-central Chile. Estuar Coast Shelf Sci 37:615-624

Jaramillo E, McLachlan A, Coetzee P (1993) Intertidal zonation patterns of macroinfauna over a range of exposed sandy beaches in south-central Chile. Mar Ecol Prog Ser 101:105-118
Kalejta B, Hockey PAR (1991) Distribution, abundance and productivity of benthic invertebrates at the Berg River Estuary, South Africa. Estuar Coast Shelf Sci 33:175-191

Kay DG, Knights RD (1975) The macro-invertebrate fauna of the intertidal soft sediments of southeast England. $J$ Mar Biol Assoc UK 55:811-832

Koop K, Griffiths CL (1982) The relative significance of bacteria, meio- and macrofauna on an exposed sandy beach. Mar Biol 66:295-300

Kristensen E (1993) Seasonal variations in benthic community metabolism and nitrogen dynamics in a shallow, organicpoor Danish lagoon. Estuar Coast Shelf Sci 36:565-586

Kurian NP, Baba M (1987) Wave attenuation due to bottom friction across the southwest Indian continental shelf. J Coast Res 3:485-490

Larsen $P(1979)$ The shallow-water macrobenthos of a northern New England estuary. Mar Biol 55:69-78

Lawrence JM, McClintock JB (1987) Intertidal invertebrate and algal communities on the rocky shores of the Bay of Morbihan, Kerguelen (South Indian Ocean). PSZN I: Mar Ecol 8:207-220

Lawton $\mathrm{JH}$ (1999) Are there general laws in ecology? Oikos 84:177-192

Leigh E, Paine RT, Quinn JF, Suchanek TH (1987) Wave energy and intertidal productivity. Proc Natl Acad Sci USA $84: 1314-1318$

Leonard GH, Levine JM, Schmidt PR, Bertness MD (1998) Flow-driven variation in intertidal community structure in a Maine estuary. Ecology 79:1395-1411

Levinton JS (1982) Marine ecology. Prentice-Hall. Englewood Cliffs, NJ

Littler MK (1980) Overview of rocky intertidal systems of southern California. In: Power DM (ed) The California Islands: proceedings of a multidisciplinary symposium. Santa Barbara Museum of Natural History, Santa Barbara, CA, p 265-306

Littler MM, Littler DS, Murray SN, Seapy RR (1991) Southern California rocky intertidal ecosystems. In: Mathieson AC, Nienhuis PH (eds) Intertidal and littoral ecosystems. Elsevier, Amsterdam, p 273-296

Loo LO, Rosenberg R (1996) Production and energy budget in marine suspension feeding populations: Mytilus edulis, Carastoderma edule, Mya arenia, and Amphiura fillformis. J Sea Res 35:199-207

Lubchenco J, Menge BA (1978) Community development and persistence in a low rocky intertidal zone. Ecol Monogr 48: $67-94$

Lubchenco J, Menge BA, Garrity SD, Lubchenco PJ, Ashkenas LR, Gaines SD, Emlet R, Lucas J, Strauss S (1984) Structure, persistence, and role of consumers in a temperate rocky intertidal community (Taboguilla Island, Bay of Panama). J Exp Mar Biol Ecol 78:23-73

Massé H (1972) Quantitative investigations of sand bottom macrofauna along the Mediterranean north Coast. Mar Biol 15:209-220

Maurer D (1977) Estuarine benthic invertebrates of Indian River and Rehoboth Bays, Delaware. Int Rev Ges Hydrobiol 62:591-629

Maurer D, Aprill G (1979) Intertidal benthic invertebrates and sediment stability at the mouth of Delaware Bay. Int Rev Ges Hydrobiol 64:379-403

McArdle BH. Gaston KJ, Lawton JH (1990) Variation in the size of animal populations: patterns, problems and artefacts. J Anim Ecol 59:439-454

McDermott JJ (1983) Food web in the surf zone of an exposed sandy beach along the Mid-Atlantic coast of the United States. In: McLachlan A, Exasmus T (eds) Sandy beaches as ecosystems. Junk Publ, The Hague, p 529-538 
McIntyre AD (1968) The meiofauna and macrofauna of some tropical beaches. J Zool 156:377-392

McLachlan A (1977a) Studies on the psammolittoral meiofauna of Algoa Bay, South Africa. II. The distribution, composition and biomass of the meiofauna and macrofauna. Zool Afr 12:33-60

McLachlan A (1977b) Composition, distribution, abundance and biomass of the macrofauna and meiofauna of four sandy beaches. Zool Afr 12:279-306

McLachlan A (1983) Sandy beach ecology: a review. In: McLachlan A, Erasmus $T$ (eds) Sandy beaches as ecosystems. Junk Publ, The Hague, p 321-380

McLachlan A (1985a) The ecology of two sandy beaches near Walvis Bay. Madoqua 14:155-163

McLachlan A (1985b) The biomass of macro- and interstitial fauna on clean and wrack-covered beaches in western Australia. Estuar Coast Shelf Sci 21:587-599

McLachlan A (1990) Dissipative beaches and macrofauna communities on exposed intertidal sands. J Coast Res 6: $57-71$

McLachlan A (1996) Physical factors in benthic ecology: effects of rhanging sand grain size on beach fauna. Mar Ecol Prog Ser 131:205-217

McLachlan A, Lombard HW, Louwrens S (1981a) Trophic structure and biomass distribution on two East Cape rocky shores. S Afr J Zool 16:85-89

McLachlan A, Wooldridge T, Dye AH (1981b) The ecology of sandy beaches in southern Africa. S Afr J Zool 16:219-231

McLachlan A, Jaramillo E, Donn TE, Wessels F (1993) Sandy beach macrofauna communities and their control by the physical environment: a geographical comparison. J Coast Res 15:27-38

McLusky DS (1987) Intertidal habitats and benthic macrofauna of the Forth estuary, Scotland. Proc R Soc Edinb B 93:389-399

McLusky DS, Desprez M, Elkaim B, Duhamel S (1994) The inner estuary of the Baie de Somme. Estuar Coast Shelf Sci 38:313-318

McQuaid CD, Branch GM (1984) Influence of sea temperature, substratum and wave exposure on rocky intertidal communities: an analysis of faunal and floral biomass. Mar Ecol Prog Ser 19:145-151

McQuaid CD, Branch GM (1985) Trophic structure of rocky intertidal communities: response to wave action and implications for energy flow. Mar Ecol Prog Ser 22:153-161

Meire PM, Seys JJ, Ysebaert TJ, Coosen J (1991) A comparison of the macrobenthic distribution and community structure between two estuaries in SW Netherlands. In: Elliott M. Ducrotoy JP (eds) Estuaries and coasts: spatial and temporal intercomparisons. ECSA19 Symposium. Olsen and Olsen, Fredensborg, p 221-230

Menge BA (1978) Predation intensity in a rocky intertidal community: relation between predator foraging activity and environmental harshness. Oecologia 34:1-16

Menge BA, Farrell TM (1989) Community structure and interaction webs in shallow marine hard-bottom communities: tests of an environmental stress model. Adv Ecol Res 19: $189-262$

Menge BA, Lubchenco J (1981) Community organization and tropical rocky intertidal habitats: prey refuges in relation to consumer pressure gradients. Ecol Monogr 51:429-450

Menge BA, Olson AM (1990) Role of scale and environmental factors in regulation of community structure. Trends Ecol Evol 5:52-57

Menge BA, Sutherland JP (1987) Community regulation: variation in disturbance, competition, and predation in relation to consumer pressure gradients. Am Nat 130:730-757
Menge BA, Daley BA, Wheeler PA, Dahlhoff E, Sanford E, Strub PT (1997) Benthic-pelagic links and rocky intertidal communities: bottom-up effects on top-down control? Proc Natl Acad Sci USA 94:14530-14535

Möller P (1986) Physical factors and biological interactions regulating infauna in shallow boreal areas. Mar Ecol Prog Ser 30:33-47

Moore HB, Davies LT, Fraser TH, Gore RH, Lopez NR (1968) Some biomass figures from a tidal flat in Biscayne Bay, Florida. Bull Mar Sci 18:261-279

Nichols FH (1977) Infaunal biomass and production on a mudflat, San Francisco Bay, California. In: Coull BC (ed) Ecology of marine benthos. Belle $W$ Baruch Library in Marine Science No. 6, University of South Carolina Press, Columbia, p 339-357

Olafsson E (1991) Intertidal meiofauna of four sandy beaches in Iceland. Ophelia 33:55-65

Paine RT (1974) Intertidal community structure: experimental studies on the relationship between a dominant competitor and its principal predator. Oecologia 15:93-120

Pamatmat MM (1968) Ecology and metabolism of a benthic community on an intertidal sandflat. Int Rev Ges Hydrobiol 53:211-298

Pearson DL, Carroll SS (1998) Global patterns of species richness: spatial models for conservation planning using bioindicator and precipitation data. Conserv Biol 12: $809-821$

Petersen GH, Curtis MA (1980) Differences in energy flow through major components of subarctic, temperate and tropical marine shelf ecosystems. Dana 1:53-64

Peterson CH (1979) The importance of predation and competition in organizing the intertidal epifaunal communities of Barnegat Inlet, New Jersey. Oecologia 39:1-24

Pugh PJA, Davenport J (1997) Colonisation vs disturbance: the effects of sustained ice-scouring on intertidal communities. J Exp Mar Biol Ecol 210:1-21

Rawlings JO (1988) Applied regression analysis: a research tool. Wadsworth and Brooks, Pacific Grove, CA

Reise K (1985) Tidal flat ecology: an experimental approach to species interactions. Springer-Verlag, Berlin

Reise K, Herre E، Sturm M (1994) Biomass and abundance of macrofauna in intertidal sediments of Königshafen in the northern Wadden Sea. Helgol Meeresunters 48:201-215

Ricciardi A, Bourget E (1998) Weight-to-weight conversion factors for marine benthic macroinvertebrates. Mar Ecol Prog Ser 163:245-251.

Riisgărd HU, Larsen PS (1995) Filter-feeding in marine macro-invertebrates: pump characteristics, modelling and energy cost. Biol Rev 70:67-106

Sanders HL, Goudsmit EM, Mills EL, Hampson GE (1962) A study of the intertidal fauna of Barnstable Harbor, Massachusetts. Limnol Oceanogr 7:63-79

SAS Instifute Inc (1988) SAS/STAT user's guide, release 603 edn. SAS Institute Inc, Cary, NC

Schwinghamer P. Hargrave B, Peer D, Hawkins CM (1986) Partitioning of production and respiration among size groups of organisms in an intertidal benthic community. Mar Ecol Prog Ser 31:131-142

Seed R (1996) Patterns of biodiversity in the macro-invertebrate fauna associated with mussel patches on rocky shores. J Mar Biol Assoc UK 76:203-210

Seed R, Lowry BJ (1973) The intertidal macrofauna of seven sandy beaches of County Down. Proc R Irish Acad Sect B Biol Geol Chem Sci 73:217-230

Shelton CR, Robertson PB (1981) Community structure of intertidal macrofauna on two surf-exposed Texas sandy beaches. Bull Mar Sci 3:833-842 
Sprung M (1994) Macrobenthic secondary production in the intertidal zone of the Ria Formosa - a lagoon in Southern Portugal. Estuar Coast Shelf Sci 38:539-558

Squires HJ (1990) Decapod Crustacea of the Atlantic coast of Canada. Can Bull Fish Aquat Sci No. 221

Straughan D (1982) Inventory of the natural resources of sandy beaches in southern California. Tech Rep Allan Hancock Found 6:1-447

Swennen C, Duiven P, Spaans AL (1982) Numerical density and biomass of macrobenthic animals living in the intertidal zone of Surinam, South America. Neth J Sea Res 15: $406-418$

Talbot MMB, Bate GC (1989) Beach morphodynamics and surf-zone diatom populations. J Exp Mar Biol Ecol 129: $231-241$

Tarr JG, Griffiths CL, Bally R (1985) The ecology of three sandy beaches on the Skeleton Coast of South West Africa. Madoqua 14:295-304

Trevallion A, Ansell AD, Sivadas P, Narayanan B (1970) A preliminary account of two sandy beaches in South West India. Mar Biol 6:268-279

Tumbiolo ML, Downing JA (1994) An empirical model for the prediction of secondary production in marine benthic invertebrate populations. Mar Ecol Prog Ser 114:165-174

Underwood AJ, Denley EJ (1984) Paradigms, explanations, and generalizations in models for the structure of inter-

Editorial responsibility: Otto Kinne (Editor),

Oldendorf/Luhe, Germany tidal communities on rocky shores. In: Strong DR, Simberloff $D$, Abele L, Thistle AB (eds) Ecological communities: conceptual issues and the evidence. Princeton University Press, Princeton, p 151-180

Ushakov PV (1965) Bionomic features of the coastal zone of the Republic of Guinea (West Africa). Okeanologiya 5: $507-517$

Warwick RM, Ruswahyuni (1987) Comparative study of the structure of some tropical and temperate marine soft-bottom macrobenthic communities. Mar Biol 95:641-649

Wendt GE, McLachlan A (1985) Zonation and biomass of the intertidal macrofauna along a South African sandy beach. Cah Biol Mar 26:1-14

Withers RG (1977) Soft-shore macrobenthos along the southwest coast of Wales. Estuar Coast Mar Sci 5:467-484

Wolff WJ, de Wolff L (1977) Biomass and production of zoobenthos in the Grevelingen Estuary, The Netherlands. Estuar Coast Mar Sci 5:1-24

Wolff WJ, Duiven AG, Duiven P, Esselink P, Gueye A, Meijboom A, Moerland G, Zegers J (1993) Biomass of macrobenthic tidal flat fauna of the Banc d'Arguin, Mauritania. Hydrobiologia 258:151-163

Wooldridge T, Dye AH, McLachlan A (1981) The ecology of sandy beaches in Transkei. S Afr J Zool 16:210-218

Zenkevitch LA (1963) Biology of the seas of the USSR. Allen and Unwin, London

Submitted: December 28, 1998; Accepted: April 9, 1999

Proofs received from author(s): July 29, 1999 